\title{
Estimating acoustic cue rates in bowhead whales, Balaena mysticetus, during their fall migration through the Alaskan Beaufort Sea
}

Susanna B. Blackwell, ${ }^{1, \text { a) }}$ Aaron M. Thode, ${ }^{2}$ Alexander S. Conrad, ${ }^{1}$ Megan C. Ferguson, ${ }^{3}$ Catherine L. Berchok, ${ }^{3}$ Kathleen M. Stafford, ${ }^{4}$ Tiago A. Marques, ${ }^{5, b)}$ and Katherine H. Kim ${ }^{1}$

${ }^{1}$ Greeneridge Sciences, Inc., 5266 Hollister Avenue, Santa Barbara, California 93111, USA

${ }^{2}$ Marine Physical Laboratory, Scripps Institution of Oceanography, University of California, San Diego, La Jolla, California 92093 , USA

${ }^{3}$ Marine Mammal Laboratory, Alaska Fisheries Science Center, National Marine Fisheries Service, National Oceanic and Atmospheric Administration, 7600 Sand Point Way Northeast, Seattle, Washington 98115, USA

${ }^{4}$ Applied Physics Laboratory, University of Washington, Seattle, Washington 98105, USA

${ }^{5}$ Centre for Research into Ecological and Environmental Modelling, School of Mathematics and Statistics, University of St Andrews, The Observatory, Buchanan Gardens, St Andrews, Fife KY16 9LZ, Scotland

\begin{abstract}
:
Eight years of passive acoustic data (2007-2014) from the Beaufort Sea were used to estimate the mean cue rate (calling rate) of individual bowhead whales (Balaena mysticetus) during their fall migration along the North Slope of Alaska. Calls detected on directional acoustic recorders (DASARs) were triangulated to provide estimates of locations at times of call production, which were then translated into call densities $\left(\mathrm{calls} / \mathrm{h} / \mathrm{km}^{2}\right)$. Various assumptions were used to convert call density into animal cue rates, including the time for whales to cross the arrays of acoustic recorders, the population size, the fraction of the migration corridor missed by the localizing array system, and the fraction of the seasonal migration missed because recorders were retrieved before the end of the migration. Taking these uncertainties into account in various combinations yielded up to 351 cue rate estimates, which summarize to a median of 1.3 calls/whale/h and an interquartile range of $0.5-5.4$ calls $/$ whale $/ \mathrm{h}$.

(C) 2021 Acoustical Society of America. https://doi.org/10.1121/10.0005043
\end{abstract}

(Received 4 November 2020; revised 30 April 2021; accepted 5 May 2021; published online 26 May 2021)

[Editor: Klaus Lucke]

Pages: $3611-3625$

\section{INTRODUCTION}

\section{A. Motivation and general concept}

In passive acoustic monitoring (PAM), an acoustic cue is an identifiable sound made by an animal of interest. When studying marine mammals, examples of cues include tonal calls, echolocation clicks, and pulsed calls such as feeding buzzes. In their most simple PAM use, these cues indicate the presence of animals within the detection range of a recorder. The cue rate expresses the mean number of cues produced per animal per unit time, for example, the average number of whistles produced by a dolphin per hour. If one of the goals of a PAM project is the estimation of animal densities via a cue-based method, then knowledge of cue rates is indispensable (Marques et al., 2013; Warren et al., 2017; Harris et al., 2018). The lack of reliable knowledge on acoustic behavior and relevant cue rates for many species is a factor that prevents broader use of passive acoustic density estimation.

a)Electronic mail: susanna@greeneridge.com, ORCID: 0000-0001-71586852.

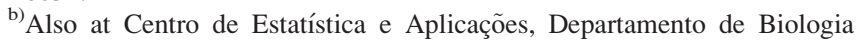
Animal, Faculdade de Ciêcias da Universidade de Lisboa, Portugal.
A seemingly straightforward way to obtain cue rates is by the use of acoustic tags that are attached to individual animals for periods of up to a few days. After retrieval of a tag and processing of the acoustic information it contains, cue rates can be calculated for the various types of sounds produced by the individual who carried the tag. With enough deployments on animals of different sex and age classes and during different behavioral states, populationlevel variable cue rates should be obtainable.

In practice, obtaining cue rates from tags is not easy. Tag deployments require substantial logistical effort, expense, and expertise, so obtaining a sufficient sample size of tagged whales is challenging. Records also need to be long enough to be representative of the normal behavior of the whale, after the initial effects of the tagging operations have subsided (e.g., Warren et al., 2020). Fortunately, due to rapid advances in tag retention, deployments lasting several days are now possible (e.g., Calambokidis et al., 2019). Another issue is that only the cues produced by the tagged individual should be included in the cue-rate calculation. Depending on the types of sounds produced and the species studied, differentiating sounds made by the tagged animal from those by other nearby untagged individuals can be challenging (Johnson, 2014; Goldbogen et al., 2014). 
Finally, assumptions must be made about how representative the acoustic behavior of a particular tagged individual is compared to the overall population's acoustic behavior. Bowhead whales (Balaena mysticetus) have been tagged with acoustic tags in only a few studies, and not enough to provide information on cue rates. In Simon et al. (2009), for example, the deployments were of short duration $(<3 \mathrm{~h})$, and no vocalizations were detected from the tagged whales.

Here, we propose a different approach for estimating cue rates in the Bering-Chukchi-Beaufort (BCB) population of bowhead whales during their westward fall migration. The general principle is simple: imagine a population of known size $N_{p o p}$ that summers in a well-defined location, such as a bay. In autumn, the population migrates out of the bay, and in doing so it passes over an array of seafloor recorders. Assume that it takes the average whale $T_{\text {array }}$ hours to swim across that array and that every whale call produced within the array is detected and counted. The mean cue rate $(C R)$ of this population, in calls per whale per hour for the types of calls produced at that particular time of the year, is calculated as follows:

$$
C R=\frac{N_{\text {calls }}}{N_{\text {pop }} \cdot T_{\text {array }}},
$$

where $N_{\text {calls }}$ is the total number of detected calls within the array.

In actuality, the procedure described in this paper for estimating BCB bowhead whale cue rates is not as straightforward as the hypothetical example above. First, the summering area of the $\mathrm{BCB}$ population is not a bay but a borderless area of the Beaufort Sea. Second, we rely on localized whale calls obtained with five arrays of recorders in an area that only covers a fraction $\left(f_{\text {corridor }}\right)$ of the geographical width of the migration corridor. Furthermore, the hydrophone arrays capture only a fraction $\left(f_{\text {migration }}\right)$ of the entire migration season, in part because not all whales migrate at the same time. As a result, these two additional factors need to be added to Eq. (1) to account for this incomplete spatial and temporal coverage,

$$
C R=\frac{\left(N_{\text {calls }} / f_{\text {corridor }}\right)}{\left(N_{\text {pop }} \cdot f_{\text {migration }}\right) \cdot T_{\text {array }}} .
$$

None of these five factors are known or can be estimated with high precision, but by appropriately defining the factors and their ranges, lower and upper bounds for population cue rates during the fall migration can be estimated. Such information is currently lacking for BCB bowheads or any other population of bowhead whales.

\section{B. Bowhead autumn migration}

The majority of the BCB population of bowhead whales typically summers in the eastern Beaufort Sea, in areas such as Amundsen Gulf, around Banks Island, and north of the Mackenzie River Delta, Canada (e.g., Moore and Reeves, 1993). Beginning in late August and continuing into October and November, whales travel westward along the
North Slope of Alaska, heading for their overwintering grounds in the Bering Sea. Unlike the eastward spring migration, when whales follow open-water leads that are often far from shore, the fall migration corridor in the Beaufort Sea is generally close and parallel to shore, mostly in water depths of 20-50 m (Würsig and Clark, 1993; Moore et al., 2000; Quakenbush et al., 2012; Citta et al., 2015; Clarke et al., 2018). Aerial surveys over many years (e.g., Miller et al., 1996; Clarke et al., 2018) have confirmed the generally westward movement of the migrating whales, but whales will opportunistically continue feeding during the migration. As a result, some individuals may linger or wander, with some whales doubling back to briefly travel eastward (e.g., Harwood et al., 2017).

\section{METHODS}

Sections II A-IIE explain in detail how we obtain estimates for the components of Eq. (2) above, including necessary assumptions and approximations. Section II A deals with $N_{\text {calls }}$, as obtained using passive acoustic recorders over eight field seasons. Section II B explains the methods used to bound $f_{\text {corridor }}$, while Sec. IIC explains the methods used to bound $f_{\text {migration. }}$ Section IID addresses the variable $N_{\text {pop }}$, while Sec. IIE addresses the array crossing time $T_{\text {array }}$. All of this information is combined to calculate bounds on cue rates in migrating bowhead whales, which are presented in Sec. III.

\section{A. Whale call database (obtaining $N_{\text {calls }}$ )}

Between 2007 and 2014, as part of their exploration activities in the Beaufort Sea, Shell Exploration and Production Company implemented an acoustic monitoring program to study the effects of industrial activities on bowhead whales (see Blackwell et al., 2013; Blackwell et al., 2015; Blackwell et al., 2017; Thode et al., 2012; Thode et al., 2016; Thode et al., 2020). Directional autonomous seafloor acoustic recorders (DASARs) were deployed at five sites (where each site consists of an array of DASARs) in the central Beaufort Sea between Kaktovik and Harrison Bay, Alaska, over an east-west distance spanning $280 \mathrm{~km}$ (Fig. 1; latitude range $70.2^{\circ}-71^{\circ} \mathrm{N}$, longitude range $\left.143.1^{\circ}-150.7^{\circ} \mathrm{W}\right)$. Each array was arranged as a grid of equilateral triangles with $7 \mathrm{~km}$ spacing between adjacent DASARs. There was some variation between years in the number of DASARs per array. For the calculations presented in this paper, we considered four arrays (sites 2-5) with seven DASARs each and one array (site 1) with three DASARs, as shown in Fig. 1. Site 4 had two different (flipped west to east) configurations over the years, each with seven DASARs: the western configuration (blue + red DASARs in Fig. 1, 2007-2011) or the eastern configuration (red + yellow DASARs in Fig. 1, 2012-2014). Site 2 could not be deployed in 2010 because of pack ice. Note, however, that 2010 deployments took place 2-3 weeks before the onset of the migration (see below), and all years included in this study were considered low-ice years (see National Snow and Ice Data Center, 2021). 


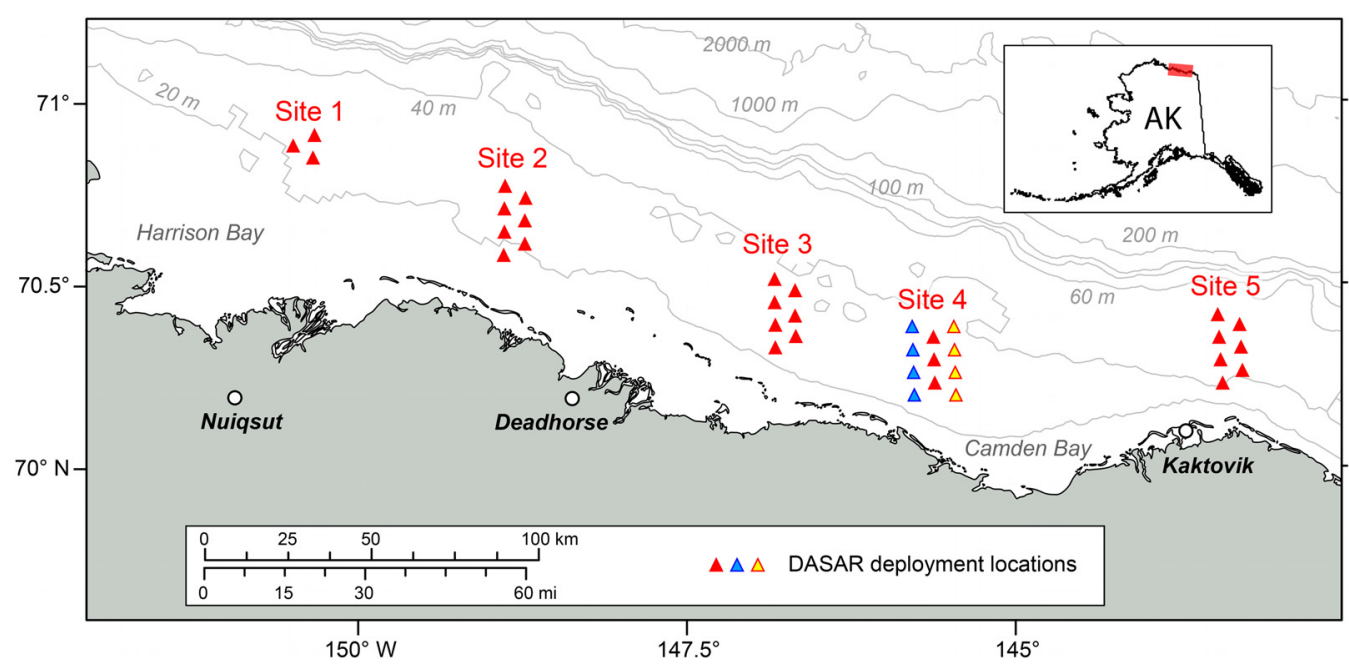

FIG. 1. (Color online) Locations of the five DASAR sites (arrays, sites 1-5) in the Beaufort Sea, 2007-2014. The inset shows the location of the map on the north coast of Alaska. Blackwell et al. (2015) includes DASAR deployment positions.

In the analysis that follows, each of the five arrays served the role of a "gate" through which migrating whales traveled during their westward migration. Specifically, we aimed to count calls in a series of adjacent circles covering the area of each array, as illustrated in Fig. 2. Sections II A 1-II A 3 provide details on the time period (the migration) over which the calls were counted as well as how call numbers were tallied.

\section{Defining the migration sampling period}

Bowhead whales are generally omnipresent in the shallow $(<50 \mathrm{~m})$ waters of the Canadian Beaufort Sea during the summer and fall (Harwood et al., 2017; Ferguson et al., 2021). Because they are traveling around during this time, presumably looking for food, there is usually not a clearly

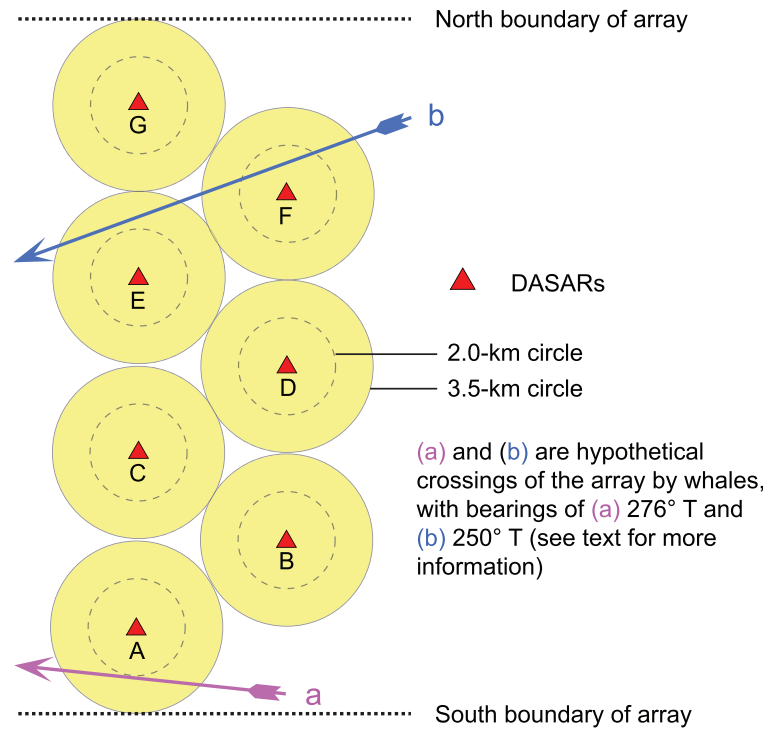

FIG. 2. (Color online) DASAR array of seven adjacent DASAR circles $(A-G)$, each of radius $3.5 \mathrm{~km}$ (2-km circles are shown with dashed lines). Dotted lines show the northern and southern boundaries of each array (when all DASARs are functional). identifiable start to the fall migration based on acoustic detections in the arrays. (DASAR deployment dates varied by year, ranging from 30 July to 26 August.) We therefore relied on local traditional knowledge from whale hunters, who place the start of the fall migration, i.e., the time when whales are consistently heading westward, near the end of August or early September (Moore and Reeves 1993; Huntington and Quakenbush, 2009; Clarke et al., 2018). With the goal of being conservative (i.e., miss the fewest migrating whales possible), the start date of the migration was arbitrarily set at 27 August for the easternmost site (site 5, see Fig. 1), 28 August for the central sites (sites 4 and 3), and 29 August for the westernmost sites (sites 2 and 1). This staggering of days accounts for the fact that at a mean speed of $5 \mathrm{~km} / \mathrm{h}$ (see Sec. IIE), a bowhead whale could cover the $280 \mathrm{~km}$ between sites 5 and 1 in $56 \mathrm{~h}$, or 2.3 days, though they likely take longer (Olnes et al., 2020). The end of data collection varied between sites and years, occurring between 28 September and 12 October (Table I).

\section{Localized call counts at each DASAR}

Bowhead whale calls were identified with an automated call detector (Thode et al., 2012), which used triangulation to localize any whale call detected simultaneously on two or more DASARs within the same array. [For more information on localization methods, see Greene et al. (2004), Blackwell et al. (2007), Blackwell et al. (2013), Blackwell et al. (2015), and Blackwell et al. (2017).] The detectability of calls and the accuracy of localizations decrease with increasing distance from the arrays (Greene et al., 2004; Thode et al., 2012; Thode et al., 2020). Two previous studies (Blackwell et al., 2015; Blackwell et al., 2017) have shown that within $2 \mathrm{~km}$ of a DASAR, there was insignificant variation in call detectability with ambient noise conditions. Here, however, calls need to be tallied in larger circles, of radius $3.5 \mathrm{~km}$, to meet the requirements of the analysis, i.e., continuous monitoring of whale calls over the north-south 
TABLE I. Periods of data collection at each site each year. The start date for tallying call localizations, i.e., the start of the migration, was the same across years: 27 August at the easternmost site 5, 28 August at the central sites 4 and 3, and 29 August at the westernmost sites 2 and 1. Site 2 could not be deployed in 2010 due to the presence of pack ice.

\begin{tabular}{lcccccc}
\hline \hline Year & Start/End & Site 1 & Site 2 & Site 3 & Site 4 & Site 5 \\
\hline All years & Start & 29 Aug. & 29 Aug. & 28 Aug. & 28 Aug. & 27 Aug. \\
2007 & End & 12 Oct. & 11 Oct. & 8 Oct. & 10 Oct. & 9 Oct. \\
2008 & End & 7 Oct. & 6 Oct. & 5 Oct. & 4 Oct. & 2 Oct. \\
2009 & End & 4 Oct. & 5 Oct. & 1 Oct. & 2 Oct. & 5 Oct. \\
2010 & End & 30 Sep. & - & 1 Oct. & 3 Oct. & 4 Oct. \\
2011 & End & 5 Oct. & 4 Oct. & 3 Oct. & 1 Oct. & 30 Sep. \\
2012 & End & 3 Oct. & 4 Oct. & 6 Oct. & 6 Oct. & 5 Oct. \\
2013 & End & 3 Oct. & 2 Oct. & 1 Oct. & 30 Sep. & 29 Sep. \\
2014 & End & 28 Sep. & 29 Sep. & 30 Sep. & 1 Oct. & 2 Oct. \\
\hline \hline
\end{tabular}

${ }^{a}$ Whale call localization ended at site 1 on 12 October 2007, but the three DASARs actually continued recording until late November 2007 (see Sec. II C).

(N-S) width of the "gate" (Fig. 2). A circle of radius $3.5 \mathrm{~km}$ has about thrice the area of a circle of radius $2 \mathrm{~km}(\sim 38.5$ versus $12.6 \mathrm{~km}^{2}$ ). All else being equal, one would therefore expect about 3 times the number of calls in the larger circles. A comparison of the number of calls localized within $3.5-\mathrm{km}$ circles versus $2-\mathrm{km}$ circles, at each site and year combination $(n=39)$ and over the entire season, showed a mean ratio \pm standard deviation (SD) of 2.53 \pm 0.2 instead of the predicted 3.06, meaning that on average, about $17 \%$ of calls were missed due to masking. ${ }^{1}$ Consequently, for each site and year combination, the number of localized calls was tallied within 2-km circles around each DASAR, starting on the late August dates listed above and ending when the recorders were retrieved. These values were multiplied by 3.06 to get estimated numbers of whale calls in the $3.5-\mathrm{km}$ circles shown in Fig. 2. This extrapolation assumption is supported by the relatively uniform distribution of whale calls across a DASAR array when viewed over an entire season. ${ }^{1}$

Knowledge of the distribution of hourly call localizations at individual DASARs helps when later interpreting results, so this variability was quantified within $2 \mathrm{~km}$ circles. ${ }^{1}$ Overall, of $197640 \mathrm{~h}$ of monitoring data at individual DASARs across all years, $78 \%$ of sampled hours were devoid of calls. The remaining $22 \%$ of sampled hours $(42849 \mathrm{~h})$ included one or more calls, indicating the nearby presence of at least one whale. Of these hours with calls present, $70 \%$ included $1-3$ calls, $92 \%$ had 10 or fewer calls, and over $99 \%$ had fewer than 30 calls.

\section{Compensating for non-functional or missing DASARs}

Adjustments had to be made for the fact that sites did not always include a full complement of functional DASARs. For example, in 2009, DASAR 3 G gave unreliable bearings that could not be used in localizations, and in 2010, DASAR 3 A could not be deployed due to ice. ${ }^{1}$ Call densities could be quite different between DASARs on a particular day, but over an entire season, the densities smoothed out. ${ }^{1}$ Therefore, if the missing DASAR was the northernmost or southernmost of an array, call counts obtained at the DASAR with the nearest latitude (within the same array) were used. If the missing DASAR was in the middle of an array, the average call count from its northern and southern neighbors was used. Table II shows the estimated numbers of whale calls for each site in each year, as adjusted for masking and missing DASAR data; they total 561001 calls over the years 2007-2014.

\section{B. Correcting call counts for spatial undersampling: Compensating for the $\mathrm{N}-\mathrm{S}$ width of the migration corri- dor (obtaining $f_{\text {corridor }}$ )}

The $\sim 28 \mathrm{~km} \mathrm{N-S}$ span of adjacent circles extending offshore at each site did not cover the full geographical width of the bowhead migration corridor, and therefore it is likely that not all whales swam through the arrays. To allow estimation of mean cue rate, the call counts shown in Table II thus need to be corrected for this incomplete spatial coverage, to account for calls generated north and south of our defined array boundaries (Fig. 2). A failure to account for these calls would lead to an undercount of the true number of whale calls being produced within the east/west boundaries of a site and a corresponding underestimation of call rate. To correct this bias, the factor $f_{\text {corridor }}$ was introduced in Eq. (2). $f_{\text {corridor }}$ requires

TABLE II. Number of localized calls at each site, each year, adjusted for calls missed due to masking and for missing data at certain sites and years (see the text), with totals in boldface. Each value is the sum of the call localizations obtained in 3.5-km circles around each DASAR of an array, over the date ranges specified in Table I. Site 2 was not deployed in 2010 due to ice. Sites are listed from west (site 1) to east (site 5).

\begin{tabular}{|c|c|c|c|c|c|c|}
\hline $\begin{array}{l}\text { Array size } \\
\text { No. of DASARs }\end{array}$ & $\begin{array}{c}\text { Site } 1 \\
3\end{array}$ & $\begin{array}{l}\text { Site } 2 \\
7\end{array}$ & $\begin{array}{c}\text { Site } 3 \\
7\end{array}$ & $\begin{array}{l}\text { Site } 4 \\
7\end{array}$ & $\begin{array}{l}\text { Site } 5 \\
7\end{array}$ & Total \\
\hline 2007 & 5119 & 11585 & 8329 & 10682 & 20074 & 55790 \\
\hline 2008 & 6141 & 30361 & 18290 & 25470 & 19045 & 99308 \\
\hline 2009 & 2335 & 4250 & 3859 & 3926 & 15802 & 30172 \\
\hline 2010 & 2111 & - & 21975 & 28008 & 14197 & 66292 \\
\hline 2011 & 2292 & 6099 & 5073 & 5935 & 1285 & 20684 \\
\hline 2012 & 2938 & 8501 & 10906 & 10491 & 12283 & 45118 \\
\hline 2013 & 18834 & 42871 & 32288 & 62213 & 12861 & 169067 \\
\hline 2014 & 5025 & 11230 & 14673 & 24844 & 18799 & 74571 \\
\hline TOTAL & 44795 & 114897 & 115393 & 171570 & 114346 & 561001 \\
\hline
\end{tabular}


independent information on the whales' spatial distribution during the autumn migration, so line-transect aerial survey data were used for this purpose. The Appendix includes complete technical details about the analysis, while a summary of the methods is presented below.

The percentage of the migration corridor covered by the DASAR arrays was estimated using bowhead whale sighting and survey effort data from the Aerial Surveys of Arctic Marine Mammals (ASAMM) project (Alaska Fisheries Science Center, 2021; Clarke et al., 2018). From these data, $90899 \mathrm{~km}$ of transect effort and 719 bowhead whale sightings were concurrent with the years of our study (2007-2014). The analysis involved a three-step process: (i) constructing spatially explicit models of bowhead whale relative abundance based on ASAMM bowhead whale sightings from September 2007-2014 (refer to whale sightings and the resultant relative abundances in Fig. 3); (ii) applying the relative abundance model to predict the expected number of bowhead whales in every cell of a $5 \times 5 \mathrm{~km}$ grid overlying the migration corridor (see the Appendix); and (iii) using the predicted number of bowhead whales in each cell to compute, for each site, $f_{\text {corridor }}$, i.e., the proportion of whales expected to be within the latitudinal range of the site (shown with white polygons in Fig. 3).

The predicted number of whales within each cell is based on the assumption of uniform survey effort throughout the study area, thereby eliminating apparent variability in bowhead whale distribution due only to spatial heterogeneity in survey effort. For each site, $f_{\text {corridor }}$ was calculated as the predicted number of whales within the north/south boundaries of the array $\left(\mu_{T O T, 1}\right.$, corresponding to the number of whales within the white polygons of Fig. 3; see the Appendix), divided by the predicted number of whales passing through the full north/south span of the migration corridor at the longitude of the array $\left(\mu_{T O T, 2}\right.$, corresponding to the number of whales within the black dashed lines of Fig. 3). Values of $f_{\text {corridor }}$ are shown in Table III; for each site, the call counts in Table II were adjusted using these $f_{\text {corridor }}$ values to yield estimated call counts, as if the entire migration corridor had been monitored at each site.

\section{Correcting raw call counts for temporal undersampling: Compensating for the duration of the migration season (obtaining $f_{\text {migration) }}$}

Another bias in the raw call counts is that they are not measured over the entire duration of the migration season. For logistical reasons, the DASAR recorders were removed in late September to early October, right before the onset of ice freeze-up. While the bulk of the bowhead migration is thought to occur from late August to late September, it is known to continue in October and into early November (e.g., Blackwell et al., 2014; Ferguson et al., 2021). For the calculations presented in this document, we need to estimate the fraction of the population missed due to removal of the recorders prior to the end of the migration (i.e., $1-f_{\text {migration }}$ ). We relied on three different passive acoustic datasets to help us estimate $f_{\text {migration }}$.

\section{Dataset (1)}

Year-round acoustic data were collected by an AuralM2 recorder $\sim 87 \mathrm{~km}$ north-northwest of site 1 [recorder

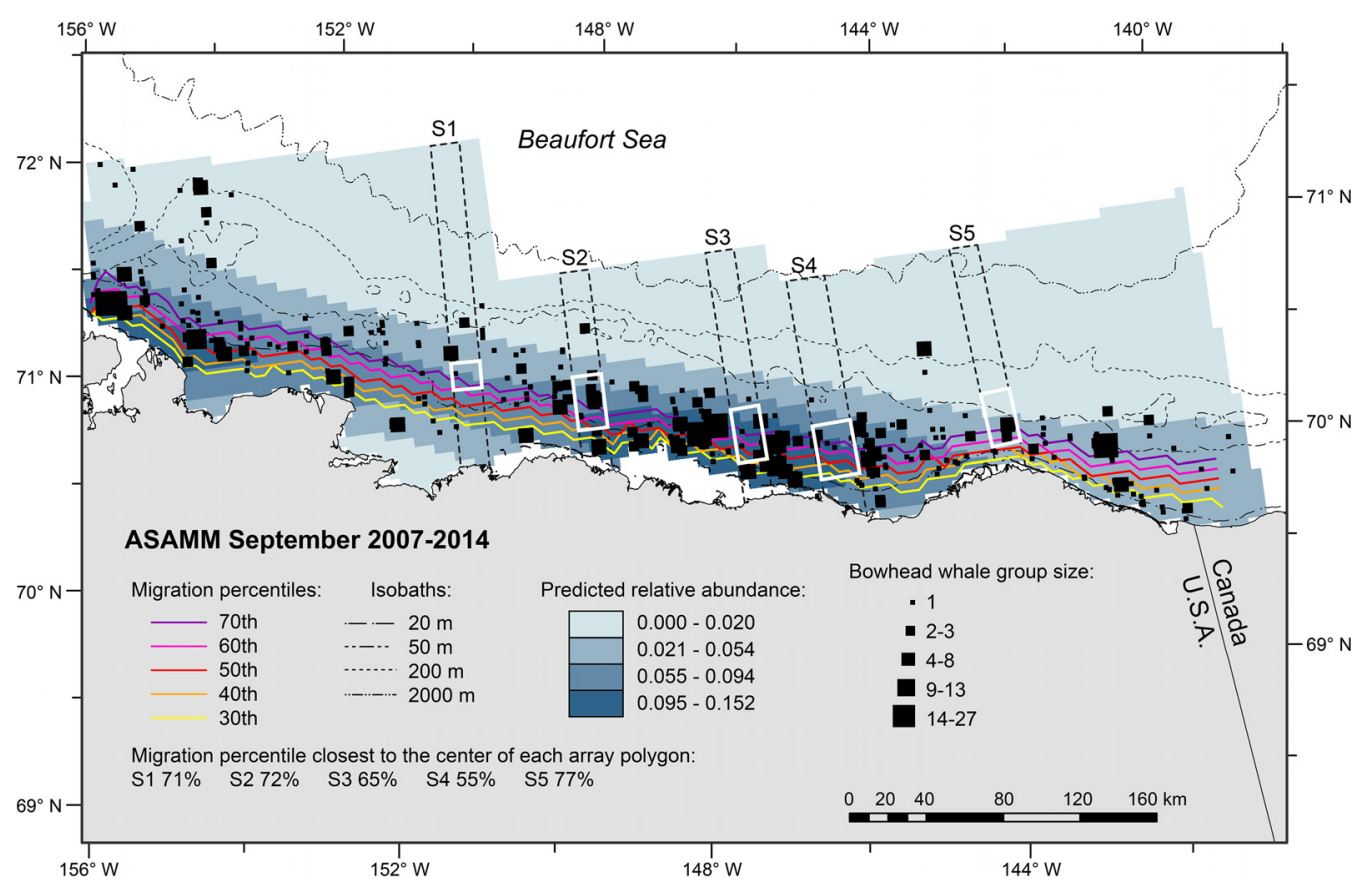

FIG. 3. (Color online) Determination of the proportion of bowhead whales migrating through the area covered by each array. ASAMM bowhead whale sighting data from the month of September in 2007-2014 (black squares) were used to construct spatially explicit models of bowhead whale relative abundance, shown with shaded areas (blue online). The parallel lines show the 30th-70th percentiles of the migration's distance to shore. The white polygons overlay each of the five sites, S1-S5 and have a width of $15 \mathrm{~km}$ (sites 1, 2, 3, and 5) or $20 \mathrm{~km}$ (for the wider site 4, see Fig. 1). The estimated number of bowhead whales in these white polygons, as a fraction of the estimated number of bowhead whales over the entire width of the migration (as delimited by the dashed black lines), defines $f_{\text {corridor }}$ (see the Appendix). 
TABLE III. Call counts at each site for each year, adjusted to include the full N-S width of the migration corridor, with totals in boldface. $f_{\text {corridor }}$ is the fraction of the bowhead migration corridor covered by the DASAR arrays during 2007-2014, as determined by aerial surveys (all years combined). For each site and year, call counts from Table II were adjusted using the listed $f_{\text {corridor }}$ value.

\begin{tabular}{|c|c|c|c|c|c|c|}
\hline$f_{\text {corridor }}$ & $\begin{array}{l}\text { Site 1 } \\
0.221\end{array}$ & $\begin{array}{l}\text { Site } 2 \\
0.523\end{array}$ & $\begin{array}{l}\text { Site } 3 \\
0.567\end{array}$ & $\begin{array}{l}\text { Site } 4 \\
0.556\end{array}$ & $\begin{array}{l}\text { Site } 5 \\
0.531\end{array}$ & Total \\
\hline 2007 & 23147 & 22140 & 14681 & 19228 & 37838 & 117035 \\
\hline 2008 & 27768 & 58024 & 32237 & 45845 & 35900 & 199774 \\
\hline 2009 & 10557 & 8123 & 6801 & 7067 & 29786 & 62333 \\
\hline 2010 & 9547 & - & 38733 & 50414 & 26761 & 125455 \\
\hline 2011 & 10363 & 11655 & 8942 & 10683 & 2423 & 44066 \\
\hline 2012 & 13282 & 16246 & 19222 & 18884 & 23153 & 90787 \\
\hline 2013 & 85158 & 81930 & 56910 & 111982 & 24243 & 360223 \\
\hline 2014 & 22718 & 21462 & 25862 & 44719 & 35436 & 150197 \\
\hline TOTAL & 202540 & 219580 & 203389 & 308823 & 215540 & 1149872 \\
\hline
\end{tabular}

152W, University of Washington (UW), blue dot in Fig. 4(a)] for the years 2008-2009 and 2011-2013. Data collection was duty-cycled at $30 \%$ (9 min of recordings every half hour). Presence/absence of bowhead calls was assessed for each 9-min file and then expressed as a daily percent time with bowhead calls present. The daily percentage of time with bowhead whales present was then expressed as a cumulative percentage for each of the 5 years [dashed blue lines, Fig. 4(b)] as well as an average across all years [blue dots, Fig. 4(b)].

\section{Dataset (2)}

Year-round acoustic data were collected by an AuralM2 recorder northeast of Utqiagivik [recorder BF2, National Oceanic and Atmospheric Administration (NOAA), yellow dot in Fig. 4(a)] for the years 2007-2009 and 2011-2014.
Different duty cycles were used over the years, with between $27 \%$ and $45 \%$ coverage. Presence/absence of bowhead calls was assessed for every $10 \mathrm{~min}$ of recorded data and expressed as a daily percent time with bowhead calls present. Data were plotted as cumulative percentages for each of the 7 years [yellow lines, Fig. 4(b)] as well as an average across all years [yellow triangles, Fig. 4(b)].

\section{Dataset (3)}

On 12 October 2007, inclement weather forced us to abandon the three site 1 DASARs [1D, 1E, and $1 \mathrm{~F}$, red dot in Fig. 4(a); see the Appendix] and retrieve them in August 2008. (Note that in 2007, these DASARs were part of a larger array, which was retrieved on 12 October.) These DASARs recorded continuously until late November 2007. Whale calls were manually analyzed on these three
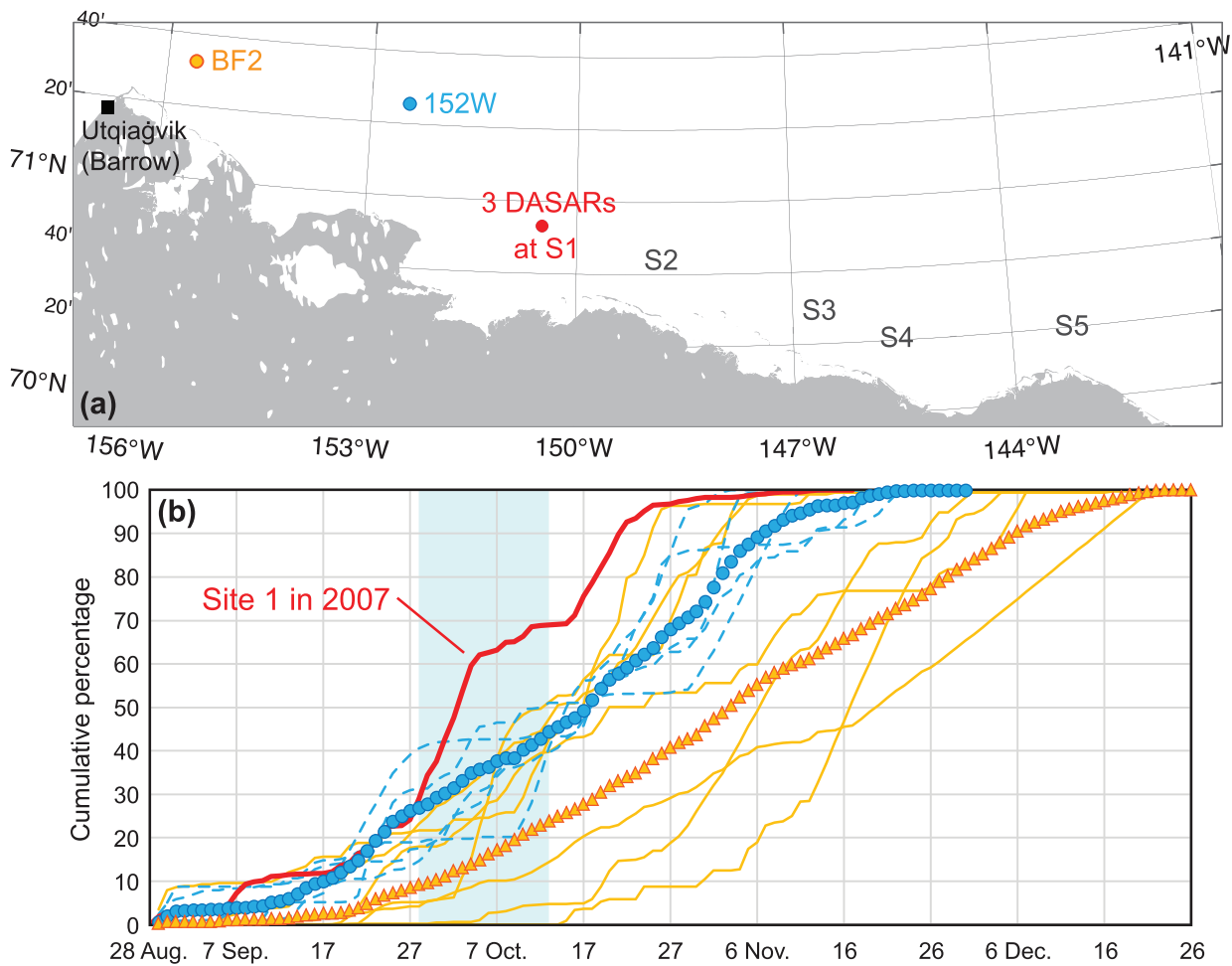

FIG. 4. (Color online) Assessing the timing of the bowhead migration. (a) Map showing the locations of recorders BF2 and $152 \mathrm{~W}$, in addition to the three DASARs at site 1 , all in relation to the other DASAR sites, indicated with S2-S5. Recorder BF2, northeast of Utqiagvik (Barrow) is $\sim 195 \mathrm{~km}$ from site 1 and $\sim 470 \mathrm{~km}$ from site 5 , while recorder $152 \mathrm{~W}$ is $\sim 87 \mathrm{~km}$ northnorthwest of site 1. (b) Daily cumulative percentage of intervals with bowhead whale detections for recorder BF2 (triangles, light-colored lines), 152W (dots, dashed lines), and the three DASARs at site 1 in 2007 (dark thick line). Lines represent data from individual years, while the symbols represent multi-year averages for each site. The shading indicates the range of retrieval dates for site 1 over the 8 years of the study. 
DASARs for the entire migration. To allow comparison with the other acoustic datasets presented above, presence/ absence of bowhead calls was assessed for the first 9 min of every half hour throughout the season, i.e., emulating a $30 \%$ duty cycle. Data were plotted as a cumulative percentage, shown with the solid red line in Fig. 4(b).

Site 1 in 2007 is the only site for which we have information on the progression of the migration. The blue shading in Fig. 4(b) shows the range of retrieval dates at site 1 during 2007-2014. When compared to the 2007 (red) cumulative percentage line, this range of retrieval dates corresponds to a fraction of missed migration $\left(1-f_{\text {migration }}\right)$ of between $70 \%$ (for a 28 September retrieval) and 30\% (for a 12 October retrieval). Figure 4(b) shows that the timing of the migration at locations $152 \mathrm{~W}$ and $\mathrm{BF} 2$ varies considerably from one year to the next, as is also known from other studies in the area covered by S1-S5 (e.g., Blackwell et al., 2007). Our goal in this paper is to estimate a range of likely cue rates produced by the whales, using the best available information for the unknowns in Eq. (2). Therefore, considering the factors above and our wish not to bound our cue rate estimates too narrowly, we settled on the assumption that the DASAR deployments missed between $25 \%$ $\left(f_{\text {migration }}=0.75\right)$ and $75 \%\left(f_{\text {migration }}=0.25\right)$ of the migrating bowhead whales. These values are used in the calculation of cue rates in Sec. III.

\section{Estimating BCB bowhead population size (estimating $\boldsymbol{N}_{\text {pop }}$ )}

Givens et al. (2013) estimated the abundance of the BCB population of bowhead whales in 2011 to be 16892 individuals, from a combination of visual sightings and acoustic locations $[95 \%$ confidence interval (CI): 15 704-18928]. They also calculated the rate of increase in the population by combining the 2011 population estimate with a time-series of visual abundance estimates, which started in 1978. As a result, they obtained an annual rate of increase in $3.7 \%$ (95\% CI: $2.8 \%-4.7 \%$ ). The 2011 abundance estimate and $3.7 \%$ yearly rate of increase were therefore used to estimate a population size for each year from 2007 to 2014 (Table IV).

\section{E. Whale travel speed and direction (estimating $T_{\text {array }}$ )}

Migrating whales require a certain time to traverse the east-west boundaries of each site, and this amount of time needs to be quantified for the calculation of cue rate. The time to traverse $\left[T_{\text {array }}\right.$ in Eq. (2)] depends on the speed of travel and the pathway (angle) across the array. Speed of travel in migrating bowhead whales in the Beaufort and Chukchi seas has been measured in several studies and has been shown to average about $5 \mathrm{~km} / \mathrm{h}$ (Mate et al., 2000; Rugh and Cubbage, 1980), with minimum and maximum values of $3.1 \mathrm{~km} / \mathrm{h}$ (Braham et al., 1980) and $7 \mathrm{~km} / \mathrm{h}$ (Zeh et al., 1993; Citta et al., 2015). The latter is considered a maximum observed migration speed of bowheads not fleeing vessels or assisted by currents.
TABLE IV. Estimated size of the BCB populations of bowhead whales $\left(N_{\text {pop }}\right)$ for the years 2007-2014, based on Givens et al. (2013). Values for all years but 2011 were estimated assuming an annual rate of increase of $3.7 \%$. The three rightmost columns represent the population sampled when $f_{\text {migration }}=75 \%, 50 \%$, or $25 \%$, where $\left(1-f_{\text {migration }}\right)$ is the fraction of the migration missed in October and early November, after the DASAR recorders have been retrieved. The columns thus display possible values for the term $N_{\text {pop }} f_{\text {migration }}$ in Eq. (2).

\begin{tabular}{lcccc}
\hline \hline & & \multicolumn{3}{c}{ Population sampled for $f_{\text {migration }}$ values of } \\
\cline { 3 - 5 } Year & $\begin{array}{c}\text { Estimated } \\
\text { abundance }\left(N_{\text {pop }}\right)\end{array}$ & $75 \%$ & $50 \%$ & $25 \%$ \\
\hline 2007 & 14607 & 10955 & 7303 & 3652 \\
2008 & 15147 & 11361 & 7574 & 3787 \\
2009 & 15708 & 11781 & 7854 & 3927 \\
2010 & 16289 & 12217 & 8144 & 4072 \\
2011 & 16892 & 12669 & 8446 & 4223 \\
2012 & 17517 & 13137 & 8758 & 4379 \\
2013 & 18165 & 13624 & 9082 & 4541 \\
2014 & 18837 & 14128 & 9418 & 4709 \\
\hline \hline
\end{tabular}

To estimate the angular distribution of migration paths across the array, we used ASAMM aerial survey data collected between longitudes $142^{\circ} \mathrm{W}$ and $152^{\circ} \mathrm{W}$ (which covers all our sites) and compiled the orientations of 120 groups (of 1-5 individuals) of whales that were seen during the month of September in 2007-2014. Groups were oriented in all cardinal directions, but the mode of the distribution was toward the west, $300^{\circ}$, with a circular mean orientation of $307^{\circ}$ T, i.e., somewhat south of northwest. However, roughly $1 / 3$ of the observed orientations had an easterly component, resulting in a wide circular SD of $85^{\circ}$. To model a distribution of migration headings, only orientations toward the west were retained and then used to construct a cumulative empirical distribution. The implications of removing eastern orientations from the heading estimates are examined in Sec. IV.

To estimate bounds on $T_{\text {array }}$, putative crossing paths of whales across the array were then simulated (see two examples in Fig. 2). First, the aforementioned heading distribution was randomly sampled 10000 times to simulate a set of migration headings that whales would take across an array. For each heading generated, a grid of parallel, putative whale paths was constructed, evenly distributed in space across the entire area of both types of arrays (7- and 3DASAR), with the paths separated by $100 \mathrm{~m}$ and all orientated along the selected heading. For each simulated path, the distance required to cross the array was calculated. (Gaps between circles were skipped, since calls localized there were not counted.) The process was then repeated for another sampled heading. The simulations tested 3323681 possible crossing paths for the large (7-DASAR) arrays (sites 2-5) and 2028344 possible crossing paths for the site 1 array. ${ }^{1}$ Because of the wide spread of headings observed and the irregular shape of the arrays, possible crossing distances varied widely, from a minimum near 0 if a crossing happened to barely intersect the circle surrounding a single DASAR to $27.5 \mathrm{~km}$ for sites $2-5$ and $14 \mathrm{~km}$ for site 1 . The 
TABLE V. Estimated values of $T_{\text {array }}$ from Eq. (2), using three different swimming speeds (3.1, 4.7, and 7 km/h) combined with a "short" and "long" crossing path through each type of array, as defined in the supplementary material (see Footnote 1). See text for more information.

\begin{tabular}{|c|c|c|c|c|}
\hline & \multicolumn{4}{|c|}{ Crossing distances } \\
\hline & \multicolumn{2}{|c|}{7 DASARs (sites 2, 3, 4, and 5) } & \multicolumn{2}{|c|}{3 DASARs (site 1) } \\
\hline & Short, $4.4 \mathrm{~km}$ & Long, $27.5 \mathrm{~km}$ & Short, $2.8 \mathrm{~km}$ & Long, $13.9 \mathrm{~km}$ \\
\hline & \multicolumn{4}{|c|}{ Time to cross (h) } \\
\hline \multicolumn{5}{|l|}{ Travel speed } \\
\hline $3.1 \mathrm{~km} / \mathrm{h}$ & 1.4 & 8.9 & 0.90 & 4.5 \\
\hline $4.7 \mathrm{~km} / \mathrm{h}$ & 0.93 & 5.8 & 0.60 & 3.0 \\
\hline $7 \mathrm{~km} / \mathrm{h}$ & 0.63 & 3.9 & 0.40 & 2.0 \\
\hline Mean & & & & \\
\hline SD & & & & \\
\hline \multicolumn{5}{|l|}{ Crossing time } \\
\hline Long duration (mean $+\mathrm{SD})$ & & & & \\
\hline Short duration (mean - SD) & & & & \\
\hline
\end{tabular}

5th and 95th percentiles of each distribution ${ }^{1}$ were used as representative "short" and "long" crossing distances.

Table V combines the three travel speed estimates and the two "short" and "long" crossing distances to yield six crossing times for each type of array, which were then averaged. This method was used instead of simply using the mean or median crossing distance from the simulations in order to establish the broadest feasible spread of crossing durations, which in turn is used to place bounds on the maximum and minimum possible cue rates. The mean crossing time $\pm \mathrm{SD}$ for sites $2-5$ is $3.6 \pm 3.3 \mathrm{~h}$, and that for site 1 is $1.9 \pm 1.6 \mathrm{~h}$. In addition to these means, the values (mean $+\mathrm{SD})$ and (mean - SD) were used in the cue-rate calculations as the "long duration" and "short duration" crossing times for each type of array (Table V).

\section{RESULTS}

Cue rates were calculated by combining Eq. (2) with the corrected call counts $\left(N_{\text {calls }} / f_{\text {corridor }}\right)$ from Table III, the three estimated sizes of the population available to the DASAR arrays $\left(N_{\text {pop }} \cdot f_{\text {migration }}\right)$ from Table IV, and three crossing times $\left(T_{\text {array }}\right)$ from Table $\mathrm{V}$ (bottom section: mean duration, long duration crossing, and short duration crossing). Altogether, these combinations yield 351 different estimates $(5$ sites $\times 8$ years $\times 3$ population estimates $\times 3$ crossing durations, minus missing data for site 2 in 2010), with a median cue rate of 1.3 calls/whale/h and an interquartile range (IQR) of $0.5-5.4$ calls/whale/h. Eighty percent of these estimates lie between 0.3 and 14.5 calls/whale/h.

Data are summarized graphically in Figs. 5 and 6. In Fig. 5, only the two extreme crossing times ("long duration" and "short duration" at the bottom of Table V) were used in the calculation of cue rates. The values in Fig. 5 therefore collectively represent upper and lower boundaries of our estimates, shown as a function of site [Fig. 5(a)] and array crossing time [Figs. 5(b) and 5(c)], for all years combined. We did this to bracket our cue rate estimates as much as possible, despite the uncertainty in several parameters that enter into these estimates.
Figure 6 shows cue rates calculated using the mean array crossing time (Table $\mathrm{V}: 3.6 \mathrm{~h}$ for sites $2-5,1.9 \mathrm{~h}$ for site 1 ), while illustrating the effect of $f_{\text {migration }}$ on the cue rate estimates: for each year and site, cue rates are shown for $f_{\text {migration }}$ values of $75 \%$ (A), $50 \%$ (B), and $25 \%$ (C). The thick purple line is placed at the median value for all cue rates shown in the figure $(n=117), 0.96$ calls/whale/h, and the shaded area shows the IQR, $0.5-1.7$ calls/whale/h.

\section{DISCUSSION}

The main finding of this analysis, illustrated in Figs. 5 and 6 , is that bowhead calling rates during the migration are only, on average, a few calls per whale per hour in the late summer and fall. Table II shows large variations in the numbers of localized whale calls among sites in the same year and from one year to the next, with differences of up to an order of magnitude. There are also substantial uncertainties in the temporal coverage, and, to a lesser extent, the spatial coverage, of the bowhead migration by the DASAR arrays. In addition, between 2007 and 2014, the bowhead population is thought to have increased by $25 \%-30 \%$ (Table IV). Nevertheless, despite these sources of variation and ambiguity, mean or median cue rates (e.g., dots and squares in Fig. 5) are surprisingly consistent for most of the site/year combinations. The overall median cue rate, which includes all 351 estimates, came to 1.3 calls/whale/h, with half the estimates between 0.5 and 5.4 calls/whale/h. In the more conservative summary in Fig. 6, calculated assuming a mean crossing time through the arrays, the median cue rate was somewhat lower, 0.96 calls/whale/h, with $99 \%$ of the estimates below 6.6 calls/whale/h.

One might wonder whether this relatively low median cue rate per animal arises from long periods of time during the migration when no whales are present, which are then occasionally punctuated by the passage of whales with an intrinsically higher cue rate. Short intervals with high cuerate animals, divided over the entire season, could produce an artificially low mean cue rate across the entire season. In actuality, the low cue rates presented in this study are 

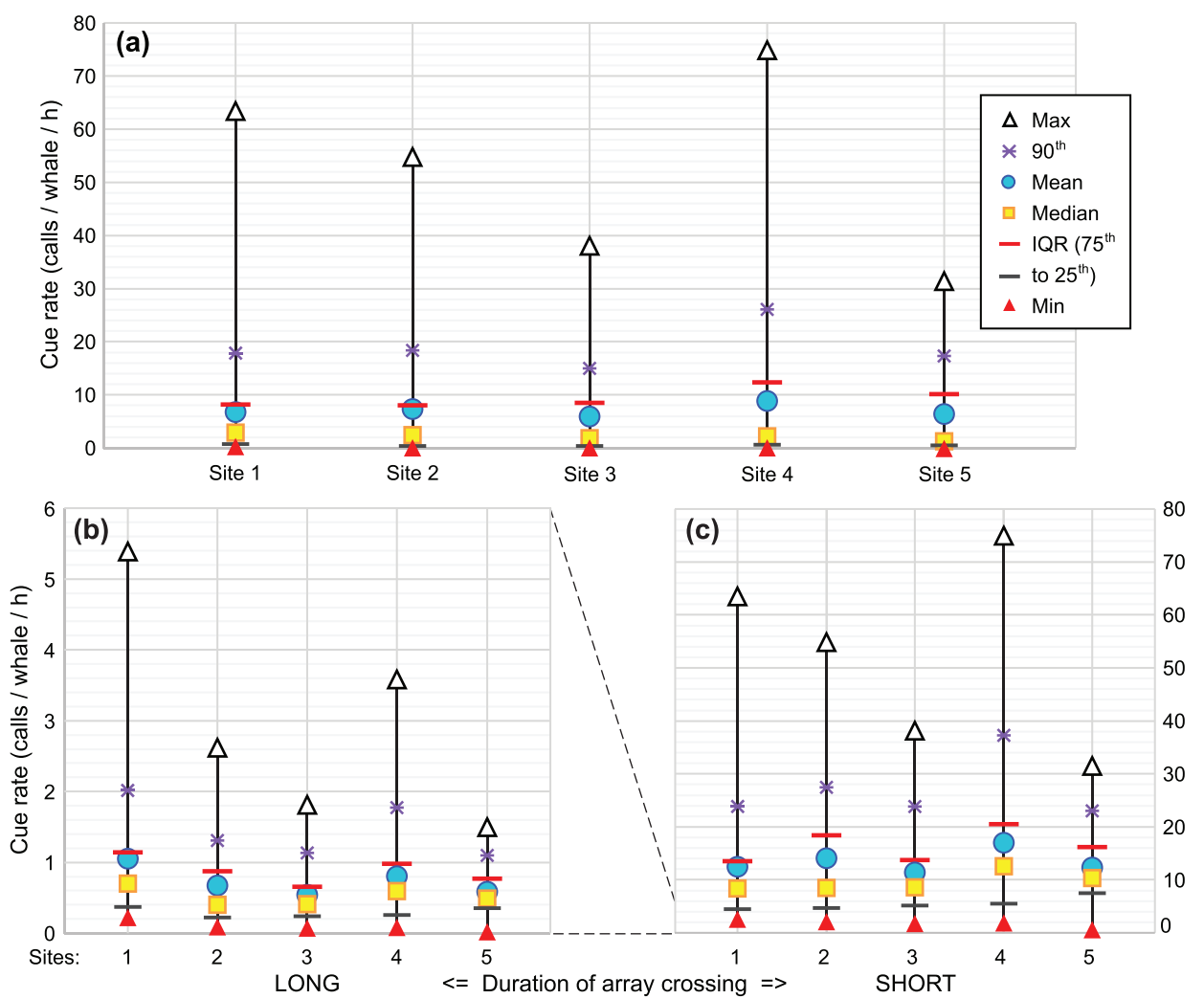

FIG. 5. (Color online) Estimated cue rates, i.e., minima and maxima, means and medians, 90th percentiles, as well as IQRs (25th-75th percentiles), for the five sites and all years combined, summarized by site and by the time taken to cross the arrays. (a) Overall summary as a function of site. Number of estimates included: 48 each for sites 1 and 3-5 and 42 for site 2. (b) and (c) Same data, shown as a function of crossing time. A long crossing time (b) is $6.9 \mathrm{~h}$ for sites $2-5$ and $3.5 \mathrm{~h}$ for site 1 , while a short crossing time (c) is $0.33 \mathrm{~h}$ for sites $2-5$ and $0.30 \mathrm{~h}$ for site 1. Number of estimates included for each summary in (b) and (c): 24 each for sites 1 and 3-5 and 21 for site 2 . Note the change in the $y$ axis scale between (b) and (c). consistent with both aerial survey observations and the distribution of hourly localized call counts at individual DASARs. ${ }^{1}$ Of all hours with at least one call localized within $2 \mathrm{~km}$ of a DASAR, $81 \%$ had fewer than five calls. Meanwhile, migrating whales most commonly travel singly or in small groups of a few individuals (e.g., Ashjian et al., 2010; Okkonen et al., 2018). At an average travel speed of $4.7 \mathrm{~km} / \mathrm{h}$, it would take up to $0.85 \mathrm{~h}$ to cross a circle of radius

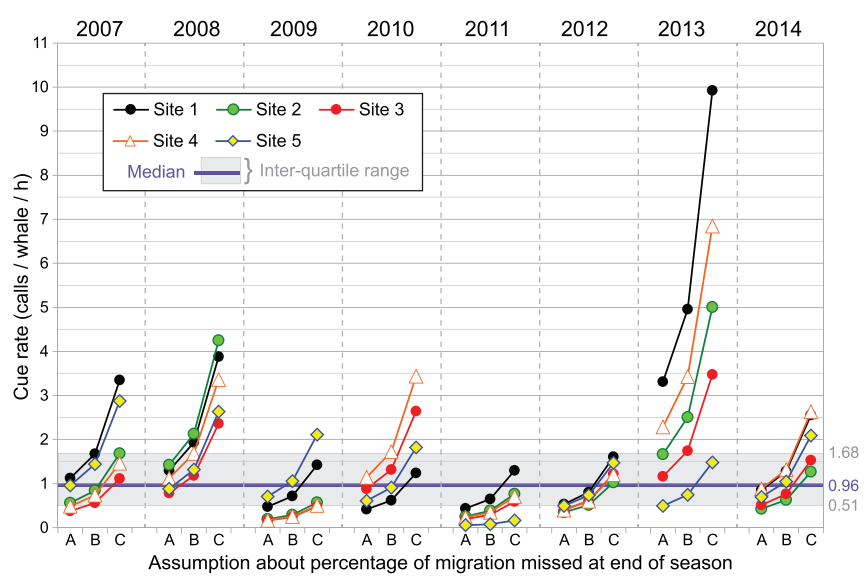

FIG. 6. (Color online) Estimated cue rates as a function of site and year, using the estimated mean crossing time through the arrays (see Table V). For each year and site combination, three cue rates were estimated ( $x$ axis labels): (A) assuming $25 \%$ of the bowhead migration was missed at the end of the season $\left(f_{\text {migration }}=0.75\right),(\mathrm{B})$ assuming $50 \%$ was missed $\left(f_{\text {migration }}=0.5\right)$, and $(\mathrm{C})$ assuming $75 \%$ was missed $\left(f_{\text {migration }}=0.25\right)$. See Table IV for details. The dark line shows the median cue rate for the combined 117 estimates included in the figure, and the shading shows the IQR (25th-75th percentiles).
$2 \mathrm{~km}$, and if calling at a rate of 1.3 calls $/$ whale $/ \mathrm{h}$, four transiting whales could thereby produce $\sim 4.4$ calls during their crossing (i.e., fewer than 5 calls/h). This simple reality check links aerial survey-based behavioral observations of group sizes with raw call counts at individual DASARs to demonstrate that the cue rates of individual animals must be on the order of only a few per hour.

Bowhead cue rates obtained here are similar to other published values for mysticetes. For example, Marques et al. (2011) obtained 1.7 calls/whale/h for North Pacific right whales (Eubalaena japonica), but, understandably, this value was based on a very small sample size. Martin et al. (2013) obtained a cue rate for minke whale (Balaenoptera acutorostrata) "boing" calls of 6 calls/whale/h, based on a single individual tracked over $\sim 12 \mathrm{~h}$. Finally, in a study combining visual sightings, acoustic recordings, and infrared camera video, Guazzo et al. (2019) obtained average cue rates for migrating Eastern North Pacific gray whales (Eschrichtius robustus) of 7.5 calls/whale/day, which corresponds to 0.31 calls/whale/h.

It is important to remember that this first attempt at estimating bowhead whale cue rates during the fall migration is, by necessity, coarse. We have pooled all age and sex classes and all call types produced by the whales. We have also assumed that all whales were in the same behavioral state (migrating). Recent satellite telemetry studies covering 2006-2018 (spanning the years of this study) have shown that $64 \%-78 \%$ of location estimates in the areas of our five sites were classified as "transiting" (Olnes et al., 2020). Therefore, our recordings could also have included sounds from whales that were lingering and/or feeding, presumably 
with different calling rates for these activities (e.g., MayCollado and Quiñones-Lebrón, 2014). We have also not taken cohort segregation into account, whereby different sex and age classes migrate at different times (Koski and Miller, 2009; Huntington and Quakenbush, 2009) and may vocalize at different rates (e.g., mother-calf pairs versus adult females without a calf). Note, however, that because this cohort segregation is not clear-cut and varies between years, our sample will likely have included whales of all sizes and both sexes, including cow-calf pairs. We have also assumed that individual cue rates do not change over the course of the autumn migration (e.g., Guazzo et al., 2019) and do not vary with whale density (e.g., Noad et al., 2017). Finally, in addition to the effects of man-made sounds on calling rates, discussed in Sec. IV B, wind-driven ambient noise levels-a natural factor-also influence call production rates (Thode et al., 2020), but no adjustment was made for this. Fortunately, the statistical distribution of ambient noise levels was consistent across all years.

\section{A. Assessing our uncertainties}

Understanding how our uncertainties affect the calculated cue rates helps increase our confidence in the values. For example, whale call counts are the primary factor that the cue rates are based upon, so what would happen if we had missed half of the calls produced within $2 \mathrm{~km}$ of all the DASARs - an extremely unlikely scenario? The median cue rate given above would simply double to 2.6 calls/whale/h, still a very low value.

When estimating bounds on $T_{\text {array }}$, aerial survey data were used to estimate the migration headings of the animals. To be consistent with the assumption of Eq. (2), all easterly orientations $\left(0^{\circ}-180^{\circ}\right)$ were removed when simulating paths across a DASAR array. What would be the impact on the results if instead some whales were allowed to temporarily migrate eastward across the arrays, as shown by the aerial survey data? We note first that if all group orientations are included in the simulations described in Sec. II E, the distribution of single-crossing $T_{\text {array }}$ times ${ }^{1}$ hardly changes. However, the 120 whale bearings from the aerial surveys show $22 \%$ of migrating groups heading toward the eastern quadrant $\left(45^{\circ}-135^{\circ}\right)$. Under an extreme-case scenario, nearly a quarter of the population $(25 \%)$, after initially crossing an array from east to west, could double back and travel back across the array west to east, before eventually doubling back once more and crossing the array for a third time. One can continue this logic and deduce that $25 \%$ of those whales that doubled back once (or $6.25 \%$ of the total population) will double back yet again and end up crossing an array five times in total, etc. If the mean time to cross the array once is $T_{\text {array }}$, then the effective mean crossing time for the entire population $T_{\text {eff }}$ becomes

$$
\begin{aligned}
T_{\text {eff }} & =T_{\text {array }}\left[\frac{3}{4}+3 *\left(\frac{1}{4}\right)+5 *\left(\frac{1}{4}\right)^{2}+7 *\left(\frac{1}{4}\right)^{3} \cdots\right] \\
& \sim T_{\text {array }}(0.75+1.22) \sim 2 T_{\text {array }},
\end{aligned}
$$

and the mean traversal time across an array for the population effectively doubles $\left(2 T_{\text {array }}\right)$. Equation (2) then shows that under this extreme scenario, the initial cue rates presented in the figures would need to be halved. In this case, the cue rates provided in Sec. III can be considered as an upper bound, which again emphasizes the low values of cue rates in migrating bowhead whales. Further analyses of bowhead whale migration directions would help determine whether the scenario discussed here is realistic.

It is important to remember that the most extreme values in the spread of cue rates shown in Figs. 5 and 6 result from a combination of our most extreme assumptions. For example, the maxima in Figs. 5(a) and 5(c) (empty triangles) were all obtained assuming $75 \%$ of the migration was missed and array crossing time was extremely short $(0.33$ and $0.3 \mathrm{~h}$, Table V) in peak calling years, 2013 for sites $1-4$ and 2007 for site 5. Similarly, the minima in Figs. 5(a) and 5 (b) (red triangles) were all obtained assuming $25 \%$ of the migration was missed and array crossing time was extremely long (6.9 and $3.5 \mathrm{~h}$, Table V) in years with low calls counts (2009-2011). Table V shows that for the 7DASAR and 3-DASAR arrays, respectively, the "long duration" array crossing times were nearly 21 and 12 times greater than the "short duration" times. This variability is reflected directly in the calculated cue rates in Fig. 5, yet $77 \%$ and $90 \%$ of the 234 estimates included in the overall summary [Fig. 5(a)] are below 10 and 20 calls/whale/h, respectively.

\section{B. Can differences between sites be explained by variable levels of man-made sounds?}

During 2007-2014, our study area included a wide range of anthropogenic activities concurrent with data collection by the DASARs. Considering there are known dose-dependent effects of certain man-made sounds-such as airgun pulses and machinery tones-on bowhead whale calling rates (Blackwell et al., 2015; Blackwell et al., 2017; Thode et al., 2020), it is worth investigating whether these external factors may have led to predictable differences in cue rates at different sites within the same year:

- In 2007, two seismic surveys (using 3147 and 20 in. $^{3}$ arrays) took place between sites 3 and 4, between midSeptember and early October. Blackwell et al. (2013) and Blackwell et al. (2015) showed that proximity to seismic operations represses calling in bowhead whales, while at greater distances, they call more than in the absence of airgun sounds. Considering the relative distances of the sites to the seismic operations, we would expect sites 3 and 4 to have lower calling rates than the other sites, which is what is shown in Fig. 6.

- In 2008, three seismic surveys (using a variety of arrays or single guns: $3147,880,440$, and $20 \mathrm{in.}^{3}$ ) took place near site 1 and between sites 3 and 4 (Blackwell et al., 2015). The two sites where heightened calling rates would be expected based on received levels of sound from the 
airguns are sites 2 and 5 , but only site 2 shows such a trend in Fig. 6.

- In 2009, there were no seismic surveys near or within our study area. There was, however, a seismic survey in Canadian waters, about $300 \mathrm{~km}$ east of site 5 , with numerous airgun pulses detected at site 5 (and many fewer at other sites). The higher cue rates at site 5 in 2009 matches our prediction.

- The 2010 deployment season was the only one with plentiful nearshore ice in the DASAR deployment area, particularly west of Prudhoe Bay. As a result, site 2 was not deployed, and site 1 had ice coverage longer than any other site, which could explain the low site 1 cue rates.

- In 2011, cue rates at all sites were low with little variation between sites. Seismic exploration was present to the north, but very distant. If any effects on calling rates were present, they should have had similar consequences on all sites.

- In 2012, Shell Exploration and Production Company performed exploratory drilling at Sivulliq, located between sites 3 and 4. Using data collected during these activities, Blackwell et al. (2017) showed a clear effect of industrial tones from vessels and other machinery on bowhead whale calling rates. Nevertheless, these hour-to-hour or day-to-day shifts would not be visible in Fig. 6, particularly considering that the largest source of tones was vessels, which during the season repeatedly transited through or near sites 1-4, while other unidentified industrial operations took place near site 5 .

- The year 2013 yielded exceptionally high call counts, with more than 8 times the number of call localizations obtained in 2011 and 1.7 times the number of calls obtained in 2008, the second-highest year (Table II; average numbers per site were compared, since only four sites were deployed in 2010). Results from another study (Kim et al., 2014) conducted over the same time period between sites 2 and 3 also showed high call counts in 2013. Additionally, the annual ASAMM aerial survey in the Beaufort Sea sighted high numbers of bowhead whales in 2013 (Clarke et al., 2014). Cue rates for scenario $\mathrm{C}$ in 2013 in Fig. 6 (75\% of the migration missed at the end of the season) were particularly high for sites 1, 2, and 4 . Nevertheless, with such large numbers of calls, it seems unlikely that as much as $75 \%$ of the migration was missed that year. It is also possible that the whales were in a different behavioral state, for example, feeding instead of migrating. If that were the case, we would expect whales to be meandering around looking for food, increasing the likelihood of them crossing an array multiple times, which in turn would have the same effect of overestimating cue rates. If we therefore ignore scenario $\mathrm{C}$, the remaining estimates for 2013 (scenarios A and B) are much closer to values obtained in previous years.

- In 2014, there were no particular industrial or other activities known to have occurred in the vicinity of our study area; obtained cue rates were consistent across sites.
The above assessment suggests specific trends in calling rates as a result of industrial operations, but the comparison remains qualitative.

\section{Seasonal specificity of calculated cue rates}

The cue rates estimated in this paper are only valid for migrating bowheads in September and early October, when the whales travel westward along the Alaskan Beaufort Sea shelf. Late summer and early fall, during the autumn migration, may be the time of the year when bowhead whales call the least. In the thousands of days of data analyzed since Greeneridge Sciences started using DASAR-based monitoring in the Beaufort Sea in 2001 (e.g., Blackwell et al., 2007), detection of a bowhead call "here and there" has been the norm, while consecutive minutes with many calls have been rare. In 2011-2012 (Blackwell et al., 2014) and 2012-2013 (unpublished), overwintering recorders were deployed in the locations of the DASAR arrays. The data obtained illustrate the changes that occur in bowhead calling at the end of the open-water season. For example, in early November, chorusing was detected, when several whales sang concurrently and nearly continuously for minutes at a time, a situation never encountered in summer recordings. Delarue et al. (2009) have reported bowhead song continuously in the Chukchi Sea in November and December, while whales were migrating southward to the Bering Sea, and then in April and May, during their return toward the Chukchi Sea. In Fram Strait, in the North Atlantic, Stafford et al. (2018) recorded complex song or call sequences nearly every hour during November to April in 2008-2014-an acoustic detection density very different from that in the summer. Finally, in the spring, as the whales pass Utqiagivik (Barrow), authors have reported both song and simpler frequency modulation (FM)-sweep calls, as whales transition back to their summer repertoire (Würsig and Clark, 1993; Johnson et al., 2015).

\section{SUMMARY AND CONCLUSION}

In this paper, a first step was taken toward estimating cue rates in bowhead whales off the North Slope of Alaska during the autumn migration. This is important because cue rates are the vital link between PAM and density estimation. Four independent datasets were combined: DASAR localization data, other PAM presence/absence data, ASAMM aerial survey data, and population estimates from Utqiagivik spring whale counts. We present cue rates obtained for eight consecutive years but believe the focus should be on the overall summary values, i.e., the median and IQR, 1.3 calls/ whale/h and 0.5-5.4 calls/whale/h, respectively. For several of the variables considered, such as the PAM call presence/ absence data and the aerial survey data, data from multiple years had to be pooled, despite knowing that both the timing and pathway of the fall migration can vary between years. The amount of exposure to airgun pulses was also quite variable in our study area during 2007-2014. Differences in cue rates at a site over two or more consecutive years could 
therefore simply be due to these external factors. Despite these complexities relating to bowhead behavior, and despite substantial uncertainties in some of our assumptions, it is encouraging that reasonable bounds on cue rates can be obtained through this approach and that these bounds are consistent across five sites and eight years. In the future, cue rates presented here may be used to monitor trends in abundance of the increasing BCB bowhead population.

While median cue rates are a good first step, knowledge of how a species' cue rates vary by season, with sex and age classes, and with behavioral state is fundamental to the application of reliable PAM density estimation. Further work on several variables, including the spread of migration headings and the fraction of the migration season missed, would reduce the spread of these bounds further. A more sophisticated analysis than the one presented here could also be envisioned using a Monte Carlo simulation approach that propagates uncertainties in all the relevant intermediary factors to the final estimates, producing a probability distribution of cue rates in migrating bowhead whales.

\section{ACKNOWLEDGMENTS}

The idea of using DASAR data to estimate cue rates was hatched years ago during a discussion between S.B.B. and Christopher S. Nations (formerly at Western EcoSystems Technology, Inc.). We thank Shell Exploration and Production Company for funding the DASAR data collection (2007-2014) and encouraging continued mining of the datasets. We also thank analysts Stephanie L. Grassia, Megan A. Wood, Kristin Otte, and Sara Tennant for help with whale call analyses and the captains and crews of the $R / V$ Norseman II, R/V Alpha Helix, R/V Westward Wind, F/V Alaskan Enterprise, F/V Mystery Bay, and F/V Aquila. Funding for the ASAMM project is from Bureau of Ocean Energy Management (BOEM) Interagency Agreements M07RG13260 and M11PG00033 (C. Monnett, R. Denton, and C. Fairfield). Funding for the NOAA mooring and analysis is from BOEM: CHAOZ-M09PG00016 (C. Monnett and H. Crowley) and ARCWEST-M12PG00021 (C. Monnett, J. Denton, and H. Crowley). Funding for the UW mooring and analysis is from National Oceanographic Partnership Program (NOPP) Grant No. N00014-08-1-0311 and National Science Foundation (NSF) Grant Nos. ARC0856244 and ARC-855828 to K.M.S. from the Office of Polar Programs of the NSF. We thank J. T. Clarke for providing us with guidance and whale heading information for the years of our study, C. S. Oedekoven and D. Harris for comments on an early version of the manuscript, and two anonymous reviewers for comments that improved the manuscript. T.A.M.'s time was covered by the Living Marine Resources (LMR) ACCURATE project (Contract No. N3943019C2176) and partial support by the Center of Statistics and its Applications (CEAUL) (funded by FCT-Fundação para a Ciência e a Tecnologia, Portugal, through Project No. UIDB/00006/2020). Reference to trade names does not imply endorsement by the National Marine
Fisheries Service or NOAA. The scientific results and conclusions, as well as any views or opinions expressed herein, are those of the author(s) and do not necessarily reflect those of NOAA or the Department of Commerce.

\section{APPENDIX: METHOD USED TO ESTIMATE $\boldsymbol{F}_{\text {corridor }}$ THE PROPORTION OF THE CORRIDOR COVERED BY THE DASAR ARRAYS}

Bowhead whale sighting and survey effort data from the ASAMM project (e.g., Clarke et al., 2018) concurrent with the years of our study (2007-2014) were used to estimate the percentage of the migration corridor covered by the DASARs. This analysis involved a three-step process: (1) constructing spatially explicit models of bowhead whale relative abundance based on ASAMM bowhead whale sightings from September in each year from 2007 to 2014; (2) applying the relative abundance model to predict the expected number of bowhead whales in every cell of a grid overlying the migration corridor; and (3) using the predicted number of bowhead whales in each cell to compute $f_{\text {corridor }}$ for each site, the proportion of whales expected to be within the northern and southern boundaries of the site.

This analysis was based on bowhead whale sightings made during transect effort by primary observers (Fig. 3). The analysis did not account for availability or perception bias because we were interested in only the proportion of the whales traveling through the region that were within acoustic detection range of each array. The analysis was conducted in $\mathrm{R}$ version 3.6.2 ( $\mathrm{R}$ Core Team, 2019) using packages sp (Pebesma and Bivand, 2005; Bivand et al., 2013), maptools (Bivand and Lewin-Koh, 2019), raster (Hijmans, 2020), rgeos (Bivand and Rundel, 2019), rgdal (Bivand, et al., 2019), and $m g c v$ (Wood, 2017).

To begin, the migration corridor was partitioned into a $5-\mathrm{km} \times 5-\mathrm{km}$ grid of cells. ${ }^{1}$ This grid resolution was chosen as a compromise between having adequate survey effort and sightings in each cell to construct models and maximizing the spatial resolution of the data.

All geospatial data were projected into an equidistant conic projection [false easting: 0.0 ; false northing: 0.0 ; central meridian: $-148.0^{\circ}$; latitude of origin: $70.75^{\circ}$; standard parallels: $69.9^{\circ}, 71.6^{\circ}$; linear unit: meter (1.0)]. Data extracted for each cell included the total number of whales sighted and the projected $x$ and $y$ coordinates of the midpoint of each cell. Bowhead whale relative abundance was modeled as a generalized additive model, parameterized by a Tweedie distribution (Tweedie, 1984; Dunn and Smith, 2005) with a natural logarithmic link function. Negative binomial models were also considered, but examination of model residuals (Ver Hoef and Boveng, 2007) suggested that the Tweedie distribution provided a better fit to the data. The model formula may be represented as

$$
\ln \left(E\left(W_{i}\right)\right)=\ln \left(\mu_{i}\right)=\alpha+s\left(X_{i}, Y_{i}\right)+\operatorname{offset}\left(\ln \left(L_{i}\right)\right),
$$


where $W_{i}$ is a random variable for the number of individual bowhead whales in cell $i$, with $W_{i}$ referring to the associated observations and $E\left(W_{i}\right)$ the expected value (mean) of $W_{i} ; \mu_{i}$ is the number of individual bowhead whales expected to be observed in cell $i ; \alpha$ is the intercept; $X_{i}$ is the projected (equidistant conic) longitude of the midpoint of cell $i$; $Y_{i}$ is the projected (equidistant conic) latitude of the midpoint of cell $i$; $s()$ is the smooth function (Wood, 2017) of location covariates used to describe bowhead whale relative abundance (this function is parameterized in the model-fitting process); and $L_{i}$ is the length $(\mathrm{km})$ of transect effort in cell $i$, which was incorporated into the model as a constant (an offset) to account for spatially heterogeneous survey effort throughout the study area.

The proportion of migrating bowhead whales expected to be within the latitudinal range of each array (between the dashed boundary lines in Fig. 2) during September of each year (2007-2014), $f_{\text {corridor, }}$, was estimated using the spatial model to predict the number of whales in two polygons: (1) a strip $15 \mathrm{~km}$ (sites 1, 2, 3, and 5) or $20 \mathrm{~km}$ wide (site 4, due to the two configurations; see Fig. 1), centered on the axis of each site, bounded on the north and south by the array boundaries (these areas are shown in Fig. 3 as white polygons), and (2) a strip of the same width as above, centered on the axis of each site, bounded on the north and south by the expected northern and southern limits of the bowhead migration corridor in September. These larger areas are delimited with black dashed lines in Fig. 3, while the migration corridor is depicted in shades of blue. The number of migrating bowheads within each polygon was calculated as (see supplementary material ${ }^{1}$ )

$$
\mu_{T O T, j}=\sum_{i=1}^{n} \frac{a_{i}}{A_{i}} \mu_{i}
$$

where $j$ is the polygon index, $j=1$ for the strip bounded by the array and $j=2$ for the strip bounded by the expected bowhead whale migration corridor; $n$ is the total number of cells intersected by polygon $j ; a_{i}$ is the area of cell $i$ contained in polygon $j ; A_{i}$ is the total area of cell $i$, which is $25 \mathrm{~km}^{2}$ for all cells; and $\mu_{T O T, j}$ is the expected total number of whales in polygon $j$.

The predicted number of whales within each cell $\left(\mu_{i}\right)$ was based on the assumption of uniform survey effort (constant $L_{i}$ for all $i$ ) throughout the study area. The magnitude of $L_{i}$ used to predict $\mu_{i}$ does not affect the resulting value of $f_{\text {corridor }}$ as long as $L_{i}$ is constant across all cells, thereby eliminating apparent variability in bowhead whale distribution due only to spatial heterogeneity in survey effort. For each site, $f_{\text {corridor }}$ was calculated as $\mu_{T O T, 1} / \mu_{T O T, 2}$ (Table II).

\footnotetext{
${ }^{1}$ See supplementary material at https://www.scitation.org/doi/suppl/ $10.1121 / 10.0005043$ for ratios of the number of calls localized within $3.5 \mathrm{~km}$ versus $2 \mathrm{~km}$ of a DASAR, an example distribution of whale calls at a site and year combination, percentage distribution of the (raw) number of localized calls detected within $2 \mathrm{~km}$ of DASARs, a table of sites and years with missing data, plots of the distribution of crossing paths across 7-DASAR and 3-DASAR arrays, and additional information pertaining to the calculation of $f_{\text {corridor }}$.
}

Alaska Fisheries Science Center (2021). "AFSC/MML: Marine mammal aerial surveys in the Bering, Chukchi, and Beaufort Seas, and Amundsen Gulf, 1979-2019," https://www.fisheries.noaa.gov/inport/item/17338 (Last viewed 17 May 2021).

Ashjian, C. J., Braund, S. R., Campbell, R. G., George, J. C., Kruse, J., Maslowski, W., Moore, S. E., Nicolson, C. R., Okkonen, S. R., Sherr, B. F., Sherr, E. B., and Spitz, Y. H. (2010). "Climate variability, oceanography, bowhead whale distribution, and Inupiat subsistence whaling near Barrow, Alaska," Arctic 63, 179-194.

Bivand, R. S., Keitt, T., and Rowlingson, B. (2019). "rgdal: Bindings for the 'geospatial' data abstraction library," R package version 1.4-8, https:// CRAN.R-project.org/package=rgdal (Last viewed 1 March 2021).

Bivand, R., and Lewin-Koh, N. (2019). "maptools: Tools for reading and handling spatial objects," R package version 0.9-9, https://CRAN.R-project.org/package=maptools (Last viewed 1 March 2021).

Bivand, R. S., Pebesma, E. J., and Gomez-Rubio, V. (2013). Applied Spatial Data Analysis with $R$ (Springer, New York).

Bivand, R., and Rundel, C. (2019). "rgeos: Interface to geometry engine-open source ('GEOS')," R package version 0.5-2, https://CRAN.Rproject.org/package=rgeos (Last viewed 1 March 2021).

Blackwell, S. B., Conrad, A. S., and Thode, A. M. (2014). "Characterizing underwater sounds at six locations in the U.S. Beaufort Sea during winter months," Joint Monitoring Program in the Chukchi and Beaufort Seas, 2012, LGL Alaska Final Report P1272-2 for Shell Offshore, Inc., ION Geophysical, Inc., and Other Industry Contributors (National Marine Fisheries Service and U.S. Fish and Wildlife Service, Washington, DC), Appendix C.

Blackwell, S. B., Nations, C. S., McDonald, T. L., Greene, C. R., Jr., Thode, A. M., Guerra, M., and Macrander, A. M. (2013). "Effects of airgun sounds on bowhead whale calling rates in the Alaskan Beaufort Sea," Mar. Mamm. Sci 29, E342-E365.

Blackwell, S. B., Nations, C. S., McDonald, T. L., Thode, A. M., Mathias, D., Kim, K. H., Greene, C. R., Jr., and Macrander, A. M. (2015). "Effects of airgun sounds on bowhead whale calling rates: Evidence for two behavioral thresholds," PLoS One 10, e0125720.

Blackwell, S. B., Nations, C. S., Thode, A. M., Kauffman, M. E., Conrad, A. S., Norman, R. G., and Kim, K. H. (2017). "Effects of tones associated with drilling activities on bowhead whale calling rates," PLoS One 12, e0188459.

Blackwell, S. B., Richardson, W. J., Greene, C. R., Jr., and Streever, B. (2007). "Bowhead whale (Balaena mysticetus) migration and calling behaviour in the Alaskan Beaufort Sea, autumn 2001-04: An acoustic localization study," Arctic 60, 255-270.

Braham, H. W., Fraker, M. A., and Krogman, B. D. (1980). "Spring migration of the western Arctic population of bowhead whales," Mar. Fish. Rev. 42, 36-46.

Calambokidis, J., Fahlbusch, J. A., Szesciorka, A. R., Southall, B. L., Cade, D. E., Friedlaender, A. S., and Goldbogen, J. A. (2019). "Differential vulnerability to ship strikes between day and night for blue, fin, and humpback whales based on dive and movement data from medium duration archival tags," Front. Mar. Sci. 6, 543.

Citta, J. J., Quakenbush, L. T., Okkonen, S. R., Druckenmiller, M. L., Maslowski, W., Clement-Kinney, J., George, J. C., Brower, H., Small, R. J., Ashjian, C. J., Harwood, L. A., and Heide-Jørgensen, M. P. (2015). "Ecological characteristics of core-use areas used by Bering-Chukchi-Beaufort (BCB) bowhead whales, 2006-2012," Prog. Oceanogr. 136, 201-222.

Clarke, J. T., Brower, A. A., Christman, C. L., and Ferguson, M. C. (2014). "Distribution and relative abundance of marine mammals in the Northeastern Chukchi and Western Beaufort seas, 2013: Annual report," OCS Study BOEM 2014-018 (U.S. Department of the Interior, Anchorage, AK).

Clarke, J. T., Ferguson, M. C., Willoughby, A. L., and Brower, A. A. (2018). "Bowhead and beluga whale distributions, sighting rates, and habitat associations in the western Beaufort Sea in summer and fall 2009-16, with comparison to 1982-91," Arctic 71, 115-138.

Delarue, J., Laurinolli, M., and Martin, B. (2009). "Bowhead whale (Balaena mysticetus) songs in the Chukchi Sea between October 2007 and May 2008," J. Acoust. Soc. Am. 126, 3319-3328.

Dunn, P. K., and Smith, G. K. (2005). "Series evaluation of Tweedie exponential dispersion model densities," Stat. Comput. 15, 267-280. 
Ferguson, M. C., Clarke, J. T., Brower, A. A., Willoughby, A. L., and Okkonen, S. R. (2021). "Ecological variation in the Western Beaufort Sea," in The Bowhead Whale Balaena mysticetus: Biology and Human Interactions, edited by J. C. George and J. G. M. Thewissen (Elsevier, London), pp. 365-379.

Givens, G. H., Edmondson, S. L., George, J. C., Suydam, R., Charif, R. A., Rahaman, A., Hawthorne, D., Tudor, B., DeLong, R. A., and Clark, C. W. (2013). "Estimate of 2011 abundance of the Bering-Chukchi-Beaufort Seas bowhead whale population," Report SC/65a/BRG01 to the Scientific Committee of the International Whaling Commission (International Whaling Commission, Cambridge, UK).

Goldbogen, J. A., Stimpert, A. K., DeRuiter, S. L., Calambokidis, J., Friedlaender, A. S., Schorr, G. S., Moretti, D. J., Tyack, P. L., and Southall, B. L. (2014). "Using accelerometers to determine the calling behavior of tagged baleen whales," J. Exp. Biol. 217, 2449-2455.

Greene, C. R., Jr., McLennan, M. W., Norman, R. G., McDonald, T. L., Jakubczak, R. S., and Richardson, W. J. (2004). "Directional frequency and recording (DIFAR) sensors in seafloor recorders to locate calling bowhead whales during their fall migration," J. Acoust. Soc. Am. 116, 799-813.

Guazzo, R. A., Weller, D. W., Europe, H. M., Durban, J. W., D'Spain, G. L., and Hildebrand, J. A. (2019). "Migrating eastern North Pacific gray whale call and blow rates estimated from acoustic recordings, infrared camera video, and visual sightings," Sci. Rep. 9, 12517.

Harris, D. V., Miksis-Olds, J. L., Vernon, J. A., and Thomas, L. (2018). "Fin whale density and distribution estimation using acoustic bearings derived from sparse arrays," J. Acoust. Soc. Am. 143, 2980-2993.

Harwood, L. A., Quakenbush, L. T., Small, R. J., George, J. C., Pokiak, J., Pokiak, C., Heide-Jørgensen, M. P., Lea, E. V., and Brower, H. (2017). "Movements and inferred foraging by bowhead whales in the Canadian Beaufort Sea during August and September, 2006-12," Arctic 70, 161-176.

Hijmans, R. J. (2020). "raster: Geographic data analysis and modeling," R package version 3.0.2, http://CRAN.R-project.org/package=raster (Last viewed 1 March 2021).

Huntington, H. P., and Quakenbush, L. T. (2009). "Traditional knowledge of bowhead whale migratory patterns near Kaktovik and Barrow, Alaska," Final report to the Barrow and Kaktovik Whaling Captains Associations, the Alaska Eskimo Whaling Commission, ConocoPhillips, and the Minerals Management Service (Alaska Department of Fish and Game, Juneau, AK).

Johnson, H. D., Stafford, K. M., George, J. C., Ambrose, W. G., Jr., and Clark, C. W. (2015). "Song sharing and diversity in the Bering-ChukchiBeaufort population of bowhead whales (Balaena mysticetus), spring 2011,” Mar. Mamm. Sci. 31, 902-922.

Johnson, M. (2014). "On-animal methods for studying echolocation in freeranging animals," in Biosonar, edited by A. Surlykke, P. E. Nachtigall, R. R. Fay, and A. N. Popper (Springer-Verlag, New York), pp. 195-229.

Kim, K. H., Norman, R. G., Burgess, W. C., Blackwell, S. B., and Greene, C. R., Jr. (2014). "Acoustic monitoring of bowhead whale migration, autumn 2013," in Monitoring of Industrial Sounds, Seals, and Bowhead Whales near BP's Northstar Oil Development, Alaskan Beaufort Sea, 2013: Annual Summary Report, edited by W. J. Richardson and K. H. Kim (BP Exploration (Alaska) Inc., Anchorage, AK).

Koski, W. R., and Miller, G. W. (2009). "Habitat use by different size classes of bowhead whales in the central Beaufort Sea during late summer and autumn," Arctic 62, 137-150.

Marques, T. A., Munger, L., Thomas, L., Wiggins, S., and Hildebrand, J. A. (2011). "Estimating North Pacific right whale Eubalaena japonica density using passive acoustic cue counting," Endang. Species Res. 13, 163-172.

Marques, T. A., Thomas, L., Martin, S. W., Mellinger, D. K., Ward, J. A., Moretti, D. J., Harris, D., and Tyack, P. L. (2013). "Estimating animal population density using passive acoustics," Biol. Rev. 88, 287-309.

Martin, S. W., Marques, T. A., Thomas, L., Morrissey, R. P., Jarvis, S., DiMarzio, N., Moretti, D., and Mellinger, D. K. (2013). "Estimating minke whale (Balaenoptera acutorostrata) boing sound density using passive acoustic sensors," Mar. Mamm. Sci. 29, 142-158.

Mate, B. R., Krutzikowsky, G. K., and Winsor, M. H. (2000). "Satellitemonitored movements of radio-tagged bowhead whales in the Beaufort and Chukchi seas during the late-summer feeding season and fall migration,” Can. J. Zool. 78, 1168-1181.
May-Collado, L. J., and Quiñones-Lebrón, S. G. (2014). "Dolphin changes in whistle structure with watercraft activity depends on their behavioral state," J. Acoust. Soc. Am. 135, EL193.

Miller, G. W., Elliott, R. E., and Richardson, W. J. (1996). "Marine mammal distribution, numbers and movements," in Northstar Marine Mammal Monitoring Program, 1995: Baseline Surveys and Retrospective Analyses of Marine Mammal and Ambient Noise Data from the Central Alaskan Beaufort Sea (BP Exploration (Alaska) Inc., Anchorage, AK), pp. 3-72.

Moore, S. E., DeMaster, D. P., and Dayton, P. K. (2000). "Cetacean habitat selection in the Alaskan Arctic during summer and autumn," Arctic 53, $341-480$.

Moore, S. E., and Reeves, R. R. (1993). "Distribution and movement," in The Bowhead Whale, edited by J. J. Burns, J. J. Montague, and C. J. Cowles (Allen Press, Lawrence, KS), pp. 313-386.

National Snow and Ice Data Center (2021). https://nsidc.org/ (Last viewed 17 May 2021).

Noad, M. J., Dunlop, R. A., and Mack, A. K. (2017). "Changes in humpback whale singing behavior with abundance: Implications for the development of acoustic surveys of cetaceans," J. Acoust. Soc. Am. 142, $1611-1618$.

Okkonen, S. R., Clarke, J. T., and Potter, R. A. (2018). "Relationships among high river discharges, upwelling events, and bowhead whale (Balaena mysticetus) occurrence in the central Alaskan Beaufort Sea," Deep-Sea Res. Pt. II 152, 195-202.

Olnes, J., Citta, J. J., Quakenbush, L. T., George, J. C., Harwood, L. A., Lea, E. V., and Heide-Jørgensen, M. P. (2020). "Use of the Alaskan Beaufort Sea by bowhead whales (Balaena mysticetus) tagged with satellite transmitters, 2006-18," Arctic 73, 278-291.

Pebesma, E. J., and Bivand, R. S. (2005). "Classes and methods for spatial data in R,” R News, http://cran.r-project.org/doc/Rnews/ (Last viewed 1 March 2021).

Quakenbush, L., Citta, J., George, J. C., Heide-Jørgensen, M. P., Small, R., Brower, H., Harwood, L., Adams, B., Brower, L., Tagarook, G., Pokiak, C., and Pokiak, J. (2012). "Seasonal movements of the Bering-Chukchi-Beaufort stock of bowhead whales: 2006-2011 satellite telemetry results," Report SC/64/BRG1 to the scientific committee of the International Whaling Commission (International Whaling Commission, Cambridge, UK).

$R$ Core Team (2019). "R: A language and environment for statistical computing," R Foundation for Statistical Computing, Vienna, Austria, http://www.R-project.org/ (Last viewed 1 March 2021).

Rugh, D. J., and Cubbage, J. C. (1980). "Migration of bowhead whales past Cape Lisburne, Alaska," Mar. Fish. Rev. 42(9-10), 46-51.

Simon, M., Johnson, M., Tyack, P., and Madsen, P. T. (2009). "Behaviour and kinematics of continuous ram filtration in bowhead whales (Balaena mysticetus)," Proc. R. Soc. B 276, 3819-3828.

Stafford, K. M., Lydersen, C., Wiig, Ø., and Kovacs, K. M. (2018). "Extreme diversity in the songs of Spitsbergen's bowhead whales," Biol. Lett. 14, 20180056.

Thode, A. M., Blackwell, S. B., Conrad, A. S., Kim, K. H., Marques, T., Thomas, L., Oedekoven, C. S., Harris, D., and Bröker, K. (2020). "Roaring and repetition: How bowhead whales adjust their call density and source level (Lombard effect) in the presence of natural and seismic airgun survey noise," J. Acoust. Soc. Am. 147, 2061-2080.

Thode, A. M., Blackwell, S. B., Seger, K. D., Conrad, A. S., Kim, K. H., and Macrander, A. M. (2016). "Source level and calling depth distributions of migrating bowhead whale calls in the shallow Beaufort Sea," J. Acoust. Soc. Am. 140, 4288-4297.

Thode, A. M., Kim, K. H., Blackwell, S. B., Greene, C. R., Jr., Nations, C. S., McDonald, T. L., and Macrander, A. M. (2012). "Automated detection and localization of bowhead whale sounds in the presence of seismic airgun surveys," J. Acoust. Soc. Am. 131, 3726-3747.

Tweedie, M. C. K. (1984). "An index which distinguishes between some important exponential families," in Statistics: Applications and New Directions: Proceedings of the Indian Statistical Institute Golden Jubilee International Conference, edited by J. K. Ghosh and J. Roy (Indian Statistical Institute, Calcutta, India), pp. 579-604.

Ver Hoef, J. M., and Boveng, P. L. (2007). "Quasi-Poisson vs. negative binomial regression: How should we model overdispersed count data?," Ecology 88, 2766-2772.

Warren, V. E., Marques, T. A., Harris, D., Thomas, L., Tyack, P. L., Aguilar de Soto, N., Hickmott, L. S., and Johnson, M. P. (2017). "Spatio-temporal variation in click production rates of beaked 
whales: Implications for passive acoustic density estimation," J. Acoust. Soc. Am. 141, 1962-1974.

Warren, V. E., Miller, P. J. O., and Tyack, P. L. (2020). "Short-term responses of sperm whales Physeter macrocephalus to the attachment of suction cup tags," Mar. Ecol. Prog. Ser. 645, 219-234.

Wood, S. N. (2017). Generalized Additive Models: An Introduction with $R$ (CRC, Boca Raton, FL).
Würsig, B., and Clark, C. (1993). "Behavior," in The Bowhead Whale, edited by J. J. Burns, J. J. Montague, and C. J. Cowles (Allen Press, Lawrence, KS), pp. 157-199.

Zeh, J. E., Clark, C. W., George, J. C., Withrow, D., Carroll, G. M., and Koski, W. R. (1993). "Current population size and dynamics," in The Bowhead Whale, edited by J. J. Burns, J. J. Montague, and C. J. Cowles (Allen Press, Lawrence, KS), pp. 409-489. 